\title{
TACTICAL DECISION MAKING TERKAIT DENGAN KEPUTUSAN SELL OR PROCESS FURTHER PRODUK GYPSUM MENGGUNAKAN PENDEKATAN DIFFERENTIAL ANALYSIS
}

\author{
Sigit Pribadi, Sri Gunawan \\ Universitas Airlangga \\ sigit.pribadi-2015@feb.unair.ac.id
}

\begin{abstract}
Gypsum is a by-product of phosphoric acid production, which is a solid waste from the extraction of P2O5 content in phosphate rock. Gypsum can be directly sold as bulk gypsum (split off point) or furtherly processed into purified gypsum. Similarly, purified gypsum can also be furtherly processed into granulated gypsum which has the lowest water and P2O5 content. A differential analysis based on the use of relevant cost data is needed to identify alternatives that provide the greatest benefits to the company, related to alternative decisions to sell gypsum at the split-off point or to process it further.

his study aims to develop a differential analysis that is used as a basis for tactical decision making related to the decision to sell gypsum products at the split-off point or to be furtherly processed into purified gypsum and/or granulated gypsum. This study uses a qualitative research approach while the research method used is a case study research method.

The result shows that the decision to furtherly process gypsum into purified gypsum and granulated gypsum generates additional profit compared to selling gypsum at the split-off point. The production and sales of granulated gypsum generate the highest profit compared to purified gypsum and bulk gypsum at the split-off point.
\end{abstract}

Keywords: Gypsum, Purified Gypsum, Granulated Gypsum, Tactical Decision Making, Differential Analysis, Relevant Cost. 


\begin{abstract}
ABSTRAK
Produk gypsum merupakan hasil samping (by product) dari produksi asam fosfat, yang merupakan limbah padatan dari ekstraksi kandungan P2O5 pada batuan fosfat. Gypsum dapat langsung dijual sebagai gypsum curah (split off point) atau diproses lebih lanjut menjadi purified gypsum. Demikian pula dengan purified gypsum, juga dapat diproses lebih lanjut menjadi granulated gypsum yang memiliki kadar air dan $\mathrm{P} 2 \mathrm{O} 5$ paling rendah serta berbentuk granul (butiran). Suatu differential analysis yang berdasar pada penggunaan data biaya relevan (relevant cost) dibutuhkan untuk mengidentifikasi alternatif-alternatif yang memberikan manfaat terbesar bagi perusahaan, terkait alternatif keputusan untuk menjual gypsum pada split off point atau diproses lebih lanjut.

Penelitian ini bertujuan untuk menyusun analisa diferensial (differential analysis) yang digunakan sebagai dasar dalam pengambilan keputusan taktis (tactical decision making) terkait keputusan untuk menjual produk gypsum pada titik pisah batas (split-off point) atau diproses lebih lanjut menjadi purified gypsum dan/atau granulated gypsum. Penelitian ini menggunakan pendekatan penelitian kualitatif sedangkan metode penelitian yang digunakan adalah metode penelitian studi kasus.

Hasil penelitian menunjukkan bahwa keputusan proses lebih lanjut (process further) produk gypsum menjadi purified gypsum dan granulated gypsum menghasilkan keuntungan (laba) tambahan dibandingkan dengan menjual gypsum pada titik pisah batas (split off point). Produksi dan penjualan granulated gypsum menghasilkan keuntungan paling tinggi dibandingkan dengan produk purified gypsum dan gypsum curah (split off point).
\end{abstract}

Kata Kunci: Gypsum, Purified Gypsum, Granulated Gypsum, Tactical Decision Making, Differential Analysis, Relevant Cost. 


\section{PENDAHULUAN}

Produk Gypsum merupakan produk samping yang dihasilkan dari produksi asam fosfat, sehingga biaya yang terbentuk dalam pabrik asam fosfat merupakan biaya bersama (joint cost) bagi produk asam fosfat, asam fluosilikat, serta gypsum. Gypsum curah yang dihasilkan dari produksi asam fosfat tersebut dapat langsung dijual untuk bahan baku dalam industri semen. Namun demikian, gypsum curah tersebut dapat dikantongi dalam ukuran kecil (kantong 50kg) dan dijual secara retail kepada masyarakat (petani) yang digunakan untuk memperbaiki sifat fisik dan kimia tanah.

Selain itu, gypsum curah dapat diproses lebih lanjut melalui proses purifikasi yaitu proses pembersihan atau pencucian produk gypsum, untuk mendapatkan produk gypsum dengan kadar P2O5 yang lebih rendah atau disebut sebagai produk purified gypsum. Produk purified gypsum tersebut dapat dijual kepada industri semen atau diproses lebih lanjut.

Granulated gypsum merupakan produk yang dihasilkan dari proses lebih lanjut purified gypsum. Purified gypsum dipanaskan dalam suhu tinggi lalu dibentuk menjadi butiran-butiran gypsum. Bentuk butiran tersebut mempermudah proses pengangkutan dan pengiriman, serta memperlancar operasional produksi di pabrik semen. Granulated gypsum tersebut juga memiliki kadar impurities (P2O5) yang paling rendah dibandingkan produk gypsum lainnya.

\section{Gambar 1}

\section{Ikhtisar Proses Bisnis Produk Gypsum}

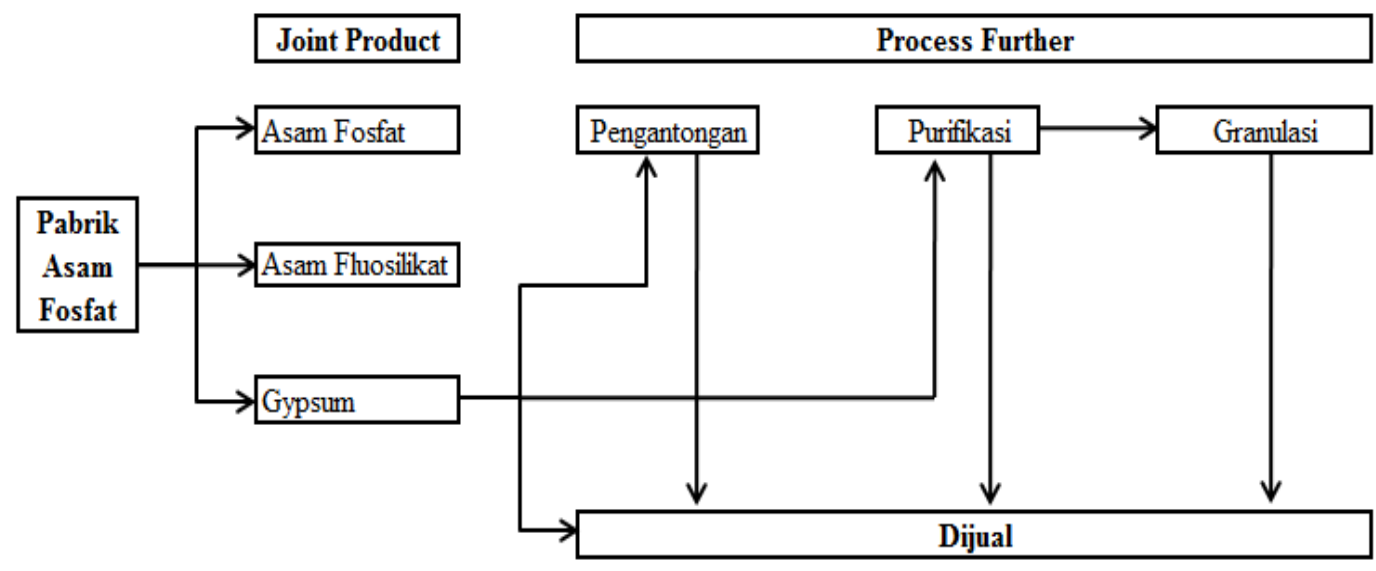

Sumber : Data internal perusahaan.

Kuantum gypsum yang dihasilkan dari produksi asam fosfat sangatlah besar (3 kali produksi asam fosfat) sehingga pengaturan distribusi hasil produksi gypsum menjadi sangat penting agar tidak menimbulkan masalah bagi perusahaan terkait dengan masalah lingkungan, 
keterbatasan tempat penyimpanan, biaya pengelolaan dan lain sebagainya. Manajemen harus membuat keputusan taktis, untuk melakukan penjualan gypsum pada split off point atau memproses lebih lanjut sehingga memberikan keuntungan yang paling besar bagi perusahaan. Keputusan taktis (tactical decision making) merupakan pemilihan dari berbagai alternatif dengan cara pandang yang segera dan terbatas (Hansen \& Mowen, 2007).

Pengambilan keputusan tersebut tentunya tidak dapat dilepaskan dengan unsur finansial perusahaan. Perusahaan harus mengetahui mengenai dampak finansial yang timbul dari setiap keputusan yang akan diambil. Akuntansi merupakan salah satu sumber utama untuk mengetahui dampak finansial atas suatu keputusan. Sistem perhitungan biaya harus terkini, fleksibel, menguntungkan, berorientasi pada masa depan dan keputusan agar dapat menghasilkan informasi operasional (Mihaela Tulvinschi, 2010). Penggunaan dasar informasi keuangan yang kurang sesuai dapat menyebabkan perusahaan melakukan kesalahan dalam pengambilan keputusan taktis sebagai contoh penggunaan data full cost dalam pengambilan keputusan, seringkali pembuat keputusan salah mengansumsikan bahwa biaya tersebut bersifat variabel dan menjadi korban dari full cost fallacy. Daniela Socea Alexandra (2012) menyatakan bahwa pada akhirnya, semua pengambilan keputusan adalah tentang masa depan. Pengambilan keputusan tidak cukup apabila hanya mengandalkan data yang hanya berkontribusi pada pemahaman tentang kinerja saat ini, namun harus juga memungkinkan pengembangan kemampuan manajemen prediktif untuk mengelola risiko secara efektif dan memungkinkan perubahan.

Kesalahan dalam penggunaan informasi keuangan dapat mengakibatkan perusahaan kehilangan potensi untuk mendapatkan laba (potential profit) karena menutup salah satu lini produksinya yang tampak rugi di laporan keuangan, padahal secara laporan manajemen lini bisnis tersebut masih menghasilkan keuntungan. Hal ini tentunya berpengaruh terhadap pencapaian laba perusahaan secara keseluruhan. Oleh karena itu, dalam pengambilan keputusan taktis harus didasarkan pada relevan cost. Sebagaimana dinyatakan oleh Kinney \& Raiborn (2011), dalam pengambilan keputusan, manajer harus mempertimbangkan semua biaya dan pendapatan yang relevan yang terkait dengan setiap alternatif keputusan.

Analisis biaya harus fokus pada penggunaan biaya relevan, dimana biaya ini tergantung pada parameter tindakan dari masalah keputusan. Sachchidanand Pachori dan Dr. Karunesh Saxena (2012) menyatakan bahwa sebuah industri harus menggunakan konsep biaya yang relevan dalam proses pengambilan keputusan khususnya di bidang keputusan kebutuhan material, membuat keputusan pembelian atau memproduksi sendiri, keputusan 
penggantian peralatan, keputusan menerima atau menolak pesanan khusus, memanfaatkan sumber daya yang langka dengan sebaik-baiknya, dan untuk menambah atau menghentikan lini produk. Managemen harus mengambil suatu keputusan untuk meningkatkan profitabilitas atau mengurangi biaya serta memastikan penggunaan bahan baku, peralatan, pabrik, dan mesin yang tepat. Selain itu juga untuk meningkatkan kompatibilitas bisnis dan mendapatkan peningkatan pangsa pasar untuk mendorong opportunity profit.

Keputusan perusahaan untuk menjual produk pada titik pisah batas (split off point) atau menjualnya setelah diproses lebih lanjut merupakan keputusan yang krusial, karena keputusan tersebut akan mempengaruhi kinerja perusahaan secara keseluruhan. Pengambilan keputusan yang tepat tentang penjualan atau proses lebih lanjut akan menaikkan margin perusahaan secara keseluruhan dan sebaliknya kesalahan dalam pengambilan keputusan dapat menyebabkan perusahaan kehilangan margin yang seharusnya didapat oleh perusahaan. Oleh karena itu, perusahaan harus menggunakan differential analysis yang berkaitan dengan penggunaan data biaya relevan (relevant cost) untuk mengidentifikasi alternatif yang memberikan manfaat terbesar bagi perusahaan terkait keputusan sell or process further produk gypsum. Hasil dari differential analysis tersebut, akan menjadi dasar perbandingan antara keuntungan yang didapatkan oleh perusahaan dari menjual produk pada split off point atau menjual produk pada proses lebih lanjut.

\section{MASALAH PENELITIAN}

Berdasarkan latar belakang dan indentifikasi permasalahan diatas, maka penulis bermaksud untuk melakukan differential analysis atas produksi dan penjualan produk gypsum, purified gypsum serta granulated gypsum. Hasil dari differential analysis tersebut, akan menjadi dasar bagi perusahaan dalam pembuatan keputusan taktis (tactical decision making) yang harus diambil oleh perusahaan terkait keputusan sell or process further produk gypsum. Sehingga rumusan masalah penelitian adalah :

1. Bagaimanakah analisa biaya differensial atas produksi dan penjualan produk gypsum, purified gypsum serta granulated gypsum?

2. Bagaimanakah tactical decision making yang harus diambil oleh perusahaan terkait keputusan sell or process further produk gypsum? 


\section{KAJIAN TEORITIS}

\section{Konsep Relevansi}

Dalam proses pembuatan keputusan oleh pihak manajemen salah satu hal yang sangat penting adalah menyajikan informasi yang relevan sebagai dasar pengambilan keputusan. Relevant costing memfokuskan atensi manajerial pada informasi yang relevan dengan keputusan (atau yang bersangkutan). Menurut Kinney \& Raiborn (2011), dalam pengambilan keputusan, manajer harus mempertimbangkan semua biaya dan pendapatan yang relevan yang terkait dengan setiap alternatif keputusan. Agar informasi menjadi relevan, harus ada tiga karakteristik:

1. Berkaitan dengan keputusan yang sedang dipertimbangkan;

2. Penting bagi pengambil keputusan; dan

3. Berhubungan dengan beberapa usaha atau tindakan di masa depan.

Menurut Datar \& Rajan (2018), biaya relevan adalah biaya yang diharapkan di masa depan dan pendapatan relevan adalah pendapatan yang diharapkan di masa depan yang berbeda antara alternatif tindakan yang dipertimbangkan. Biaya dan pendapatan yang tidak relevan disebut irrelevant. Penting untuk mengenali bahwa biaya yang relevan dan pendapatan yang relevan harus:

1. Terjadi di masa depan - setiap keputusan berhubungan dengan manajer untuk memilih suatu tindakan berdasarkan atas hasil yang diharapkan di masa depan.

2. Berbeda antara setiap alternatif tindakan - biaya masa depan dan pendapatan yang tidak berbeda tidak akan menjadi masalah dan, oleh karena itu, tidak akan berpengaruh pada keputusan yang dibuat.

Hansen dan Mowen (2007) berpendapat bahwa biaya yang relevan adalah biaya masa depan yang berbeda antar alternatif. Semua keputusan berhubungan dengan masa depan. Oleh karena itu, hanya biaya masa depan yang bisa relevan dengan keputusan. Namun, untuk menjadi relevan, biaya tidak hanya harus menjadi biaya masa depan tetapi juga harus berbeda dari satu alternatif ke alternatif lainnya. Jika biaya masa depan sama untuk lebih dari satu alternatif, tidak ada pengaruhnya terhadap keputusan tersebut. Biaya seperti itu adalah biaya yang tidak relevan (irrelevant).

\section{Differential Analysis}

Dalam setiap pengambilan keputusan, seorang manajer membutuhkan perbandingan atas satu alternatif terhadap alternatif yang lainnya. Perbandingan tersebut digunakan untuk menentukan bagaimana biaya dan pendapatan akan terpengaruh ketika suatu alternatif telah 
dipilih dibandingkan dengan alternatif lainnya. Proses perbandingan antara suatu alternatif terhadap alternatif lainnya tersebut disebut sebagai differential analysis. Menurut Anderson \& Maher (2014) differential analysis merupakan suatu proses mengestimasikan pendapatan dan biaya dari alternatif tindakan yang tersedia untuk pembuatan keputusan dan melaukukan perbandingan estimasi tersebut dengan status quo. Differential analysis dapat digunakan untuk membuat keputusan mengenai menjual produk pada tahap intermediate atau produk tersebut diproses lebih lanjut (Reeve, 2012).

Differential analysis dilakukan dengan membandingkan biaya dan pendapatan yang berbeda dalam setiap alternatif. Biaya dan pendapatan yang berbeda dalam setiap alternatif yang dipertimbangkan disebut sebagai differential cost dan differential revenue (Anderson \&Maher,2014). Salah satu kategori biaya yang penting untuk diidentifikasi ketika pengambilan keputusan adalah biaya yang telah terjadi di masa lalu dan tidak dapat diubah oleh keputusan yang akan dibuat. Biaya tersebut disebut sebagai sunk cost dan biaya tersebut tidak relevan dalam pengambilan keputusan.

\section{METODOLOGI}

Strategi atau pendekatan penelitian yang dipakai dalam penelitian ini adalah pendekatan penelitian kualitatif. Pendekatan kualitatif digunakan untuk dapat menjawab pertanyaan penelitian yang mengharuskan peneliti untuk melakukan eksplorasi secara mendalam terhadap permasalahan yang diajukan. Penelitian kualitatif mengidentifikasi tujuan tertentu melalui teknik yang memungkinkan peneliti untuk melakukan penafsiran secara mendalam terhadap suatu fenomena tanpa bergantung kepada pengukuran numerik (Zikmund, 2015). Penelitian tersebut fokus untuk memahami makna inti dan menghasilkan pengertian yang mendalam.

Pendekatan penelitian yang digunakan adalah studi kasus dengan cara mengamati dan mengumpulkan catatan data dan dokumen yang ada untuk menyelidiki fenomena yang ada di perusahaan. Menurut Yin (2003) studi kasus merupakan pendekatan yang sesuai apabila pokok pertanyaan dalam penelitian berhubungan dengan pertanyaan "how" dan "why", serta apabila peneliti hanya mempunyai sedikit peluang untuk mengontrol peristiwa yang akan diselidiki dan bilamana fokus penelitiaannya terletak pada fenomena kontemporer di dalam konteks kehidupan nyata.

Penelitian yang dilakukan didasarkan pada ketertarikan peneliti pada topik penelitian, yaitu pengambilan keputusan taktis terkait menjual atau memproses lebih lanjut produk gypsum. Penelitian ini diawali pada pemahaman proses bisnis gypsum, serta pengumpulan 
dan analisa data keuangan dan non keuangan. Tahap selanjutnya difokuskan pada identifikasi biaya dan pendapatan yang relevan dengan keputusan, pada setiap tahapan proses produksi gypsum sehingga dapat disusun differential analysis sebagai dasar untuk pembuatan keputusan taktis terkait sell or process further produk gypsum.

Untuk memperoleh dan menghimpun data yang dibutuhkan dalam penelitian ini penulis melakukan pengumpulan data dan keterangan-keterangan yang diperoleh secara tertulis dari dokumen internal perusahaan yang berhubungan dengan keputusan sell or process further produk gypsum, seperti melalui pencatatan dan pengkopian laporan, dokumen, catatan, dan informasi lainnya yang berhubungan keputusan tersebut yang berupa laporan produksi, laporan penjualan, alur atau proses bisnis gypsum, alur alokasi biaya, serta laporan keuangan perusahaan.

Selain itu, untuk memperoleh pemahaman yang komprehensif terkait dengan proses bisnis dari produksi dan penjualan produk gypsum, penulis juga melakukan wawancara dengan karyawan-karyawan kunci di perusahaan. Penulis melakukan wawancara dengan karyawan kunci dari produksi Departemen III A untuk memahami proses produksi dan penyimpanan gypsum. Selanjutnya penulis, juga melalukan wawancara dengan karyawan kunci dari Departemen Penjualan Produk Non Pupuk (PPNPJ) untuk memperoleh pemahaman tentang proses penjualan dan pemasaran produk gypsum. Terakhir, penulis akan melakukan wawancara dengan karyawan kunci dari Departemen Akuntansi, bagian Akuntansi Biaya, untuk melakukan konfirmasi terkait realisasi proses bisnis gypsum dengan pola perhitungan harga pokoknya sehingga akan diperoleh pemahaman yang utuh terkait pola perhitungan serta sifat masing-masing biaya yang membentuk harga pokok produk gypsum dan turunannya.

\section{PEMBAHASAN}

Dalam pembuatan keputusan, manajer atau pembuat keputusan harus mempertimbangkan biaya dan manfaat yang dihasilkan dari setiap alternatif keputusan yang akan diambil. Seorang manajer harus menilai keputusan mana yang akan menciptakan benefit yang lebih besar bagi perusahaan. Sebagaimana dinyatakan oleh Robert J. Lempert (2014) analisis biaya manfaat bertujuan untuk membantu orang membuat keputusan yang lebih baik dimana dalam keadaan yang tepat, individu dan organisasi yang pilihannya sesuai dengan yang disarankan oleh analisis biaya manfaat akan mengalokasikan sumber daya yang paling efisien dan dengan demikian mendapatkan pencapaian yang lebih baik daripada mereka yang pilihannya menyimpang dari yang direkomendasikan oleh analisis biaya manfaat. 
Keputusan taktis yang harus dibuat oleh manajer atau pimpinan di sebuah perusahaan seringkali melibatkan sejumlah data yang besar sebagai dasar dalam pengambilan keputusan tersebut. Namun demikian, tidak semua data yang tersedia di perusahaan, relevan dengan keputusan yang akan diambil. Demikian pula dengan PT X, untuk pengambilan keputusan tentang sell or process further produk gypsum, PT X harus membuat differential analysis yang berkaitan dengan penggunaan data biaya relevan (relevant cost). Sebagaimana dinyatakan oleh Dr. Omah Ishmael dan Osamor I. P. (2012) dimana konsep biaya relevan sangat penting dalam pengambilan keputusan bagi manager karena akan memperkuat kebutuhan untuk menyoroti perbedaan halus antara biaya yang relevan dan biaya diferensial. Hal ini akan meningkatkan kinerja yang lebih baik bagi manajer dan organisasi secara keseluruhan ketika pengeluaran biaya yang tepat ikut dipertimbangkan dalam pembebanan/alokasi biaya ke dalam pusat biaya. Selain itu, penetapan biaya yang relevan memberikan cara yang sangat berguna untuk menilai apakah perusahaan yang menunjukkan kerugian pada tingkat marjinal bersih masih layak dalam jangka pendek (Mohammad Mazibar Rahman dan Saiful Islam, 2014).

Berkaitan dengan hal tersebut diatas, penyusunan laporan relevan cost sebagai data inputan untuk melakukan analisa diferensial (differential analysis) dalam pengambilan keputusan sell or process further produk gypsum melalui dua tahapan, yaitu melakukan perhitungan tambahan pendapatan atas proses lebih lanjut (incremental revenue) dan mengidentifikasi biaya-biaya yang relevan dengan keputusan sell or process further produk gypsum (incremental cost), dengan rincian sebagai berikut:

1. Perhitungan Incremental Revenue

Incremental revenue merupakan tambahan pendapatan yang diperoleh perusahaan apabila dilakukan proses lebih lanjut. Dalam penelitian ini, perhitungan incremental revenue didapatkan dari perkalian antara kuantum penjualan produk hasil proses lebih lanjut dengan selisih harga jual antara proses lebih lanjut dibandingkan proses sebelumnya.

Tabel 1

Perhitungan Tambahan Pendapatan atas Process Further Gypsum (Incremental Revenue)

\begin{tabular}{|l|r|r|r|}
\hline \multicolumn{1}{|c|}{ Keterangan } & \multicolumn{1}{c|}{ Gypsum Inbag } & \multicolumn{1}{c|}{ Purified Gypsum } & Granulated Gypsum \\
\hline Penjualan setelah proses lebih lanjut & 3.758 .159 .400 & 79.824 .212 .910 & 61.110 .681 .462 \\
(-) Penjualan pada proses sebelumnya & $(1.098 .542 .946)$ & $(24.792 .499 .704)$ & $(20.787 .961 .848)$ \\
\hline Tambahan pendapatan dari proses lebih lanjut & $\mathbf{2 . 6 5 9 . 6 1 6 . 4 5 4}$ & $\mathbf{5 5 . 0 3 1 . 7 1 3 . 2 0 5}$ & $\mathbf{4 0 . 3 2 2 . 7 1 9 . 6 1 4}$ \\
\hline
\end{tabular}

Sumber : Data internal perusahaan yang diolah 
2. Identifikasi Biaya Relevan untuk Perhitungan Incremental Cost

Dalam pengambilan keputusan untuk sell or process further produk gypsum, manajemen perusahaan harus mendasarkan pada penggunaan biaya relevan (relevant cost). Perusahaan harus mengidentifikasi biaya-biaya yang tidak relevan terhadap keputusan sell or process further produk gypsum dan mengeluarkan irrelevant cost tersebut dari perhitungan. Tabel 2 menunjukkan proses identifikasi biaya-biaya yang tidak relevan sehingga didapatkan perhitungan incremental cost sebagai salah satu komponen yang digunakan sebagai dasar dalam pengambilan keputusan sell or process further produk gypsum.

Tabel 2

Identifikasi Biaya Tidak Relevan

\begin{tabular}{|l|l|r|r|r|r|}
\hline \multirow{2}{*}{ No. Keterangan } & \multicolumn{3}{|c|}{ (Irrelevant Cost) } \\
\cline { 3 - 6 } & & Gypsum Curah & Gypsum Kantong & Purified Gypsum & Granulated Gypsum \\
\hline 1. & Joint Cost & 191.588 .170 & 68.753 .945 & 112.046 .809 & 15.518 .598 .847 \\
2. & Biaya Gaji Tidak Langsung & - & - & 10.113 .668 .951 & 6.079 .080 .440 \\
3. & Biaya Overhead Pemeliharaan & - & - & 4.321 .278 .837 & 1.922 .789 .969 \\
4. & Sunk Cost (Biaya Penyusutan) & - & - & 15.003 .446 .749 & 2.811 .383 .121 \\
5. & Biaya Alokasian atas Overhead Pabrik & - & - & 13.124 .300 .504 & 3.434 .758 .726 \\
6. & Biaya Alokasian atas Beban Usaha & 1.002 .057 .053 & 4.024 .819 .327 & 3.791 .428 .566 & 1.999 .460 .290 \\
\hline
\end{tabular}

Sumber : Data internal perusahaan yang diolah

Pada tabel 2 dilakukan identifikasi terkait biaya-biaya yang tidak relevan dengan keputusan sell or process further produk gypsum dan mengeluarkan irrelevant cost tersebut dari perhitungan biaya produk dengan penjelasan sebagai berikut:

a. Joint Cost

Biaya yang membentuk Harga Pokok Penjualan (HPP) produk gypsum curah pada split off point seluruhnya merupakan biaya alokasi dari joint cost pabrik asam fosfat. Oleh karena itu, seluruh biaya pembentuk Harga Pokok Penjualan (HPP) produk gypsum curah tidak relevan apabila digunakan dalam pengambilan keputusan sell or process further produk gypsum. Biaya atas joint cost tersebut tetap terjadi, baik perusahaan menjual maupun tidak menjual produk gypsum curah.

b. Biaya Gaji Tidak Langsung

Biaya gaji tidak langsung merupakan pembebanan biaya gaji dari unit-unit penunjang yang berkontribusi terhadap produksi produk gypsum dan turunannya. Biaya gaji tidak langsung lebih bersifat biaya bersama (common cost) sehingga tidak relevan terhadap keputusan sell or process further produk gypsum. Biaya gaji tidak langsung tetap timbul atas keputusan perusahaan untuk menjual atau memproses gypsum lebih lanjut. 
c. Biaya Overhead Pemeliharaan

Biaya overhead pemeliharaan merupakan biaya yang timbul di cost center pemeliharaan. Biaya di cost center pemeliharaan tersebut sebagian besar merupakan biaya gaji dan kesejahteraan, serta penggunaan barang-barang habis pakai di unit pemeliharaan. Biaya overhead pemeliharaan dialokasikan kepada unit penerima jasa pemeliharaan berdasarkan realisasi jam pemeliharaan (aktivitas pemeliharaan) di masing-masing unit kerja. Dengan demikian, berdasarkan sifat biayanya tersebut diatas, biaya overhead pemeliharaan merupakan irrelevant cost terhadap keputusan sell or process further produk gypsum.

d. Biaya Penyusutan

Biaya penyusutan merupakan pembebanan secara sistematis atas nilai perolehan suatu aset sepanjang masa manfaat aset tersebut. Biaya penyusutan merupakan sunk cost yaitu biaya yang telah terjadi dan tidak dapat dipulihkan sehingga tidak dapat diubah dengan pembuatan keputusan baik saat ini maupun di masa yang akan datang.

e. Biaya Alokasian atas Overhead Pabrik Lainnya

Biaya alokasian atas overhead pabrik merupakan biaya bersama (common cost) dari biaya unit kerja yang memberikan kontribusi kepada unit produksi. Biaya tersebut dialokasi secara proporsional sesuai cost driver-nya kepada unit produksi yang memperoleh manfaat dari unit kerja tersebut. Oleh karena itu, biaya alokasian atas overhead pabrik merupakan biaya yang tidak relevan terhadap keputusan menjual atau memproses lebih lanjut gypsum.

f. Biaya Alokasian atas Beban Usaha

Beban usaha yang dibebankan pada produk gypsum terdiri atas biaya penjualan, biaya administrasi umum, dan biaya bunga. Biaya administrasi umum dan biaya bunga tidaklah relevan karena merupakan biaya alokasi yang tidak berbeda pada setiap keputusan yang akan diambil. Biaya penjualan terdiri dari biaya penjualan langsung seperti trucking, bongkar muat, freight dan biaya penjualan tidak langsung yang merupakan alokasi dari overhead penjualan. Biaya penjualan langsung relevan dengan keputusan sedangkan biaya penjualan tidak langsung merupakan biaya yang tidak relevan dengan keputusan.

Dalam melakukan analisa differensial atas keputusan sell or process further, maka perusahaan harus membuat perbandingan antara potensi tambahan pendapatan yang diperoleh dalam proses lebih lanjut dengan tambahan biaya yang dikeluarkan untuk memproses lebih lanjut produk tersebut. Perbandingan antara tambahan pendapatan dengan tambahan biaya atas proses lebih lanjut, akan mencerminkan kinerja keuangan atas pemrosesan lebih lanjut 
suatu produk, dimana apabila tambahan pendapatan lebih tinggi daripada tambahan biayanya maka perusahaan memperoleh laba atas proses lebih lanjut tersebut. Namun sebaliknya, apabila tambahan pendapatan lebih rendah daripada tambahan biayanya, hal tersebut memiliki arti perusahaan akan mengalami kerugian apabila perusahaan memproses produk tersebut lebih lanjut.

Tabel 3

Differential Analysis atas Keputusan Sell or Process Further Produk Gypsum

\begin{tabular}{|c|c|c|c|c|c|}
\hline \multirow{2}{*}{ No. } & \multirow{2}{*}{ Keterangan } & \multicolumn{4}{|c|}{ Differential Anabysis } \\
\hline & & Gypsum Curah & Gypsum Kantong & Purified Gypsum & Granulated Gypsum \\
\hline 1. & Penjualan pada split off point & 5.268 .035 .938 & - & - & - \\
\hline 2. & Penjualan setelah proses lebih lanjut & - & 3.758 .159 .400 & 79.824.212.910 & 61.110 .681 .462 \\
\hline 3. & (-) Penjualan pada proses sebelumnya & - & 1.098.542.946 & 24.792.499.704 & 20.787.961.848 \\
\hline 4. & Tambahan pendapatan dari proses lebih lanjut & - & 2.659 .616 .454 & 55.031 .713 .205 & 40.322 .719 .614 \\
\hline 5. & $\begin{array}{l}\text { Dikurangi biaya dari proses lebih lanjut } \\
\text { - Proses pengantongan } \\
\text { - Proses purifikasi } \\
\text { - Proses granulasi }\end{array}$ & - & 2.674 .534 .506 & 28.023.294.703 & 28.774.570.977 \\
\hline 6. & Laba / (rugi) kotor dari proses lebih lanjut & 5.268 .035 .938 & $(14.918 .053)$ & 27.008 .418 .502 & 11.548 .148 .637 \\
\hline 7. & Dikurangibiaya penjualan & 607.457 .262 & 136.616 .562 & 24.821 .590 .770 & 7.120 .304 .850 \\
\hline 8. & Laba / (rugi) bersih & 4.660 .578 .676 & $(151.534 .615)$ & 2.186 .827 .732 & 4.427 .843 .787 \\
\hline
\end{tabular}

Sumber : Data internal perusahaan yang diolah

Dalam analisis differensial dengan menggunakan data relevant costing pada tabel 3 menunjukkan bahwa perusahaan lebih baik untuk menjual produk gypsum setelah proses lebih lanjut, berupa produk granulated gypsum dan purified gypsum dibandingkan dengan menjual produk gypsum curah pada split off point. Penjualan gypsum pada proses lebih lanjut menghasilkan tambahan margin sebesar Rp4,43 Miliar untuk produk granulated gypsum dan sebesar Rp2,19 Miliar untuk produk purified gypsum.

Adanya tambahan laba atas proses lebih lanjut, memiliki arti bahwa tambahan manfaat (incremental revenue) atas proses lanjutan (proses purifikasi dan granulasi) lebih tinggi daripada tambahan biaya (incremental cost) yang dikeluarkan oleh perusahaan untuk menjalankan proses purifikasi dan granulasi tersebut. Oleh karena itu, berdasarkan analisa diferensial, lebih menguntungkan bagi perusahaan untuk melakukan penjualan produk gypsum setelah proses purifikasi dan granulasi daripada menjual produk gypsum curah pada split off point.

Namun demikian, untuk penjualan gypsum dalam kantong, perusahaan sebaiknya melakukan penjualan gypsum curah pada split off point daripada menjual produk gypsum dalam kantong, karena tambahan aktvitas pengantongan menyebabkan penurunan keuntungan 
yang didapatkan oleh perusahaan. Dengan kata lain, tambahan pendapatan dari penjualan gypsum dalam kantong tidak mampu menutup tambahan biaya atas aktivitas pengantongan tersebut. Oleh karena itu, penjualan gypsum dalam kantong menghasilkan margin negatif sehingga akan menggerus laba perusahaan.

Berdasarkan hasil perhitungan dari differential analysis maka penulis merekomendasikan perusahaan untuk mengambil keputusan taktis (tactical decision making) terkait dengan keputusan sell or process further produk gypsum, berupa mengoptimalkan produksi dan penjualan granulated gypsum sebagai prioritas pertama, lalu melakukan produksi dan penjualan purified gypsum sebagai prioritas kedua. Sedangkan proses lebih lanjut berupa pengantongan gypsum curah untuk dihentikan karena berkontribusi negatif terhadap kinerja perusahaan dan prioritas terakhir adalah melakukan penjualan produk gypsum pada split off point (penjualan gypsum curah) untuk meminimalkan pengiriman gypsum curah ke area penyimpanan sementara (disposal).

\section{KESIMPULAN}

Differential analysis atas keputusan sell or process further produk gypsum di PT X menunjukkan bahwa keputusan proses lebih lanjut (process further) produk gypsum menjadi purified gypsum dan granulated gypsum menghasilkan keuntungan (laba) tambahan dibandingkan dengan menjual gypsum pada titik pisah batas (split off point), sedangkan proses pengantongan produk gypsum akan mengurangi laba perusahaan. Produksi dan penjualan granulated gypsum menghasilkan keuntungan paling tinggi dibandingkan dengan produk purified gypsum dan gypsum curah (split off point).

Berdasarkan hasil dari differential analysis tersebut, maka lebih menguntungkan bagi PT X untuk menghentikan penjualan gypsum kantong, mengoptimalkan produksi dan penjualan granulated gypsum dibandingkan dengan purified gypsum dan sisanya dipenuhi dari penjualan gypsum curah. 


\section{DAFTAR PUSTAKA}

Alexandra, Daniela Socea. 2012. Managerial Decision Making and Financial Accounting Information. Procedia - Social and Behavioral Sciences 58 (2012), 47-55.

Datar, Srikant M. \& Mandhav V. Rajan. 2018. Hongren's Cost Accounting : A Managerial Emphasis. $16^{\text {th }}$ edition. New York: Pearson Education, Inc

Hansen, Don R., Maryanne M. Mowen, and Liming Guan. 2007. Cost Management: Accounting and Control. $6^{\text {th }}$ edition. Mason: South-Western Cengage Learning

Hansen, Don R. \& Maryanne M. Mowen. 2007. Managerial Accounting. $8^{\text {th }}$ edition. Mason: Thomson South-Western

Ishmael, Dr. Omah dan Osamor I. P. 2012. Relevant Cost Concept : A Glaring DichotomyAccountant's Perspective. Australian Journal of Business and Management Research, Vol.2 No.03, 25-33.

Kinney, Michael R. \& Cecily A. Raiborn. 2011. Cost Accounting: Foundations and Evolutions. $8^{\text {th }}$ edition. Mason: South-Western Cengage Learning

Lanen, William N., Shannon W Anderson, and Michael W. Maher. 2014. Fundamentals of Cost Accounting. New York: McGraw-Hill Irwin

Lempert, Robert J. 2014. Embedding (some) Benefit-Cost Concepts into Decision Support Processes with Deep Uncertainty. Journal of Benefit-Cost Analysis, Vol.5 Issue 3, 487514.

Pachori, Sachchidanand dan Dr. Karunesh Saxena. 2012. Relevant Costing : A Concept For Costing Decision In Indian Automotive Industry. International Conference on Humanities, Economics and Geography.

Rahman, Mohammad Mazibar dan Saiful Islam. 2014. The Impact of Relevant Costing for Decision Making in Ready Made Garments (RMGs) Industry of Bangladesh. IOSR Journal of Business and Management, Vol.16, Issue 3 Ver I, 01-07.

Reeve, James M., Carl S. Warren, Jonathan E. Duchac. 2012. Principles of Managerial Accounting. $11^{\text {th }}$ edition. Mason: South-Western Cengage Learning

Tulvinschi, Mihaela. 2010. Relevant Cost for Decision in an Effective Controlling System. Theoretical and Applied Economics, Vol.XVII No.05(546), 49-58.

Yin, Robert K. 2003. Case Study Research: Design and Methods. $3^{\text {th }}$ edition. London: SAGE Publications.

Zikmund, et al. 2015. Business Research Methods, International Edition 8th ed. Canada: South-Western Cengage Learning. 